\title{
ONLINE EDUCATION EXPERIENCES OF THE STUDENTS STUDYING IN HEALTH CARE DEPARTMENTS DURING THE COVID-19 PANDEMIC
}

\author{
Dr. Dilek BAYKAL \\ ORCID: 0000-0001-5965-9318 \\ Istanbul Atlas University \\ Faculty of Health Sciences \\ Istanbul, TURKEY \\ Sema KOC TUTUNCU \\ ORCID: 0000-0003-0038-3817 \\ Maltepe University \\ Vocational School \\ Medical Services and Techniques Department \\ Istanbul, TURKEY
}

Received: 25/11/2020 Accepted: 27/04/2021

\begin{abstract}
The COVID-19 pandemic interrupted face to face education and lead the transition to online education in Turkey, as it happened all around the world. The aim of this study is to describe the feelings, opinions, and experiences of the students of health departments about online education. In this qualitative study, interviews were conducted with 40 students in Turkey. The content analysis revealed five themes: (1) ambivalent feelings, (2) feelings of advantages and disadvantages, (3) differences of online education from face to face education, (4) problems experienced, and (5) recommendations. The students of health departments had various feelings such as happiness and worry in the first days of online education. Throughout the online education, students also could not benefit from applied courses. Moreover, the students experienced problems stemming from themselves, the system, and, even if a little, from the teaching staff.
\end{abstract}

Keywords: Covid-19, students, experience, online education, qualitative study.

\section{INTRODUCTION}

COVID-19 spread to 187 countries and territories in a short time in 5 months after it was first reported in Wuhan, China. The virus which affected 6.2 million people was declared an international pandemic by the World Health Organization (WHO) on 30 January 2020. The first case in Turkey was announced by the Republic of Turkey Ministry of Health on 11 March (COVID-19 Information page. https://www.saglik. gov.tr/; Cucinotta \& Vanelli, 2020). After the first case, the measures taken throughout the country were increased. The pandemic affected many sectors starting from the health care system. The education system was also one of the sectors affected by the virus. All around the world, 1.5 billion students and 63 million educators had to be away from their usual education environment (UNESCO, 2020a; 2020b).

After the announcements of the WHO, Turkey decided not to continue face to face education (Akbulut et al., 2020). With the fact that education would continue online, the education administrators began to look up for online education tools. Many online teaching platforms (such as Adobe, Moodle, Zoom, etc.) are used for online education (Reimers, 2020; ETF, 2020). These and similar programs were used also in universities in Turkey, and education went on online. 
The students studying in health departments of the universities have applied courses as well as theoretical ones. Moreover, the students studying in health departments have applied courses in clinical environments, directly intervened with human health. However, since it would create a serious risk for students to involve in clinics in terms of public health, it was announced by the Chairmanship of the Higher Education Board that all of the courses (both theoretical and applied) would be held online in distance (Press briefing. https:// www.yok.gov.tr).

The students studying in health departments have the opportunity to reinforce what they have learned with practical training as well as theoretical courses. Laboratories and clinical practices provide a wide range of opportunities to reflect the theoretical knowledge learned in the classroom into practice (Culyer et al., 2018). In this way, students learn how to provide care for the patient with various illnesses (Brashers et al., 2016). However, following COVID, students and educators who were away from the educational environment had to switch to online education. This might have caused some adaptation problems for both the students and teachers. Yet, there are a limited number of studies conducted in Turkey evaluating education during the COVID process. (Ozer, 2020a; Akbulut et al., 2020; Ozer, 2020b; Aker \& Midik 2020; Pinar \& Akgul, 2020; Ozdin \& Bayrak Ozdin, 2020; Ertug, 2020; Keskin Kiziltepe \& Kurtgoz, 2020). It is seen that these studies are either compilations or quantitative studies, and they are conducted for the evaluation of the parameters such as attitudes, satisfaction, anxiety, and stress.

Understanding the feelings, thoughts, and experiences of the students during this process can contribute to enhancing the quality of the education and benefit of the students in the 2020-2021 academic year which is expected to continue online. For this reason, it is aimed in this study to understand the feelings, thoughts, and experiences of the students about online education after COVID.

\section{METHODS}

\section{Design}

A qualitative design is used in line with the aim of the study (Polit $\&$ Beck, 2010). Semi-structured interviews with open-ended questions were made with the students studying in health departments. The interviews were made through platforms such as Zoom and Adobe using cameras (optional) and voice recordings instead of face-to-face interviews as a requirement of isolation rules during the COVID epidemic.

The interviews were held August-September 2020 and were recorded and transcribed verbatim. A content analysis was performed to identify five themes. And these are ambivalent feelings, feelings of advantages and disadvantages, the differences between online education than face to face education, the problems experienced, and recommendations.

Before starting the study, the ethics committee's permission was taken from the Research Ethics Committee (07.10.2020/No:08-01). Moreover, the necessary permissions were also taken from the XXX (2020-0708T23_18_43). In accordance with the Declaration of Helsinki, participants received verbal and written information about the study. After explaining the purpose of the study, the consents of the participants were taken.

\section{Sample}

The students studying in the health departments (Midwifery, nursing, anesthesia, first aid, and emergency, medical imaging techniques) of two private universities were included in the study. The reason why the study is conducted with the students in health departments is that they have both theoretical and practical courses. For this reason, it would give a better understanding of online education experiences during COVID in terms of both theoretical and practical courses. Following the explanation of the aim of the study, 40 students who were volunteered and gave permission for their voice records to be taken were included in the study.

\section{Data Collection}

Data were collected via demographical information (age, gender, department, and GPA) form and semistructured form for online education experiences during COVID. Open-ended questions were asked in the 
semi-structured interview form and the opinions, experiences, and recommendations of the students were aimed to be obtained (Table 1).

Before starting the interviews, pilot interviews were held with 3 students to ensure the suitability and richness of the content. The data obtained from these 3 students were not included in the study. The interviews were made between August - September. Before the meeting, an appointment was made from participants for the appropriate hours and days. The students were called and the date and time of which they were available were indicated. Interviews were conducted by both researches. The interviews lasted 20-45 minutes, and the audio/video recorded and transcribed verbatim shortly thereafter.

Table 1. The Open-Ended Questions Asked to the Students

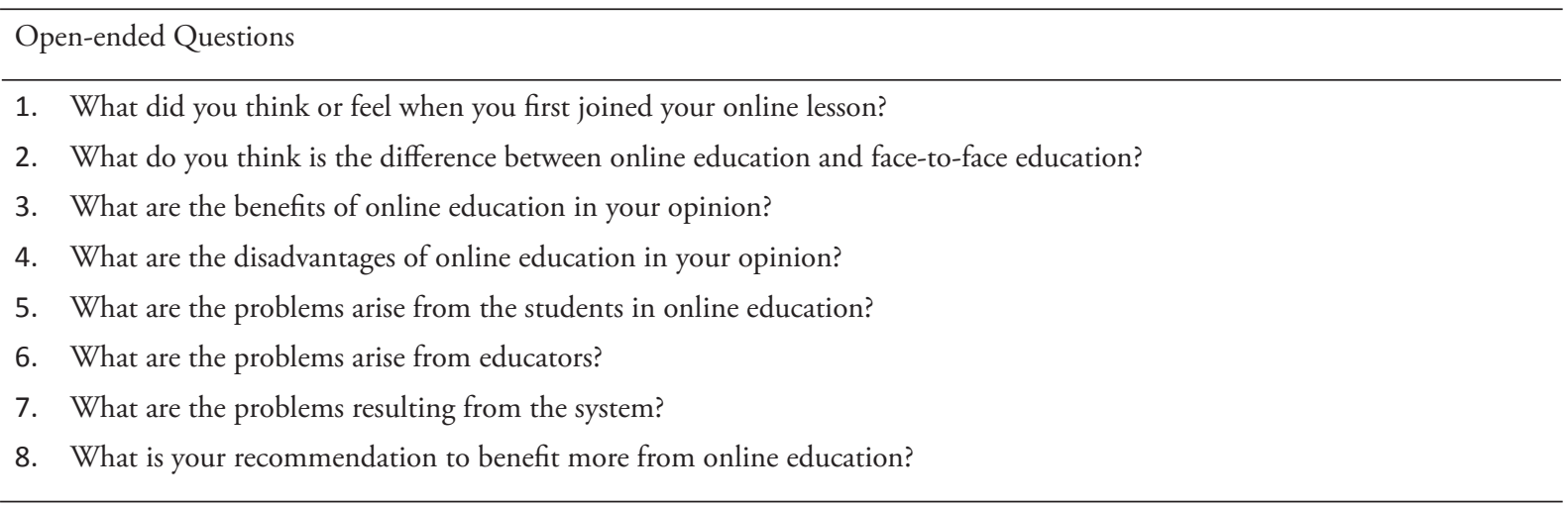

\section{Data Analysis}

Content analysis was used for the analysis of the interviews. The content analysis focuses on variations in the meanings of the content in participants' narrations (Krippendorff, 2013). The transcriptions were made after the interviews. The transcriptions were analyzed in detail. Two researchers independently coded the themes in order to reduce subjectivity during the creation of the themes. After the codes were created, an agreement was achieved upon the mutual codes. It was made sure that the themes and categories created were the representation of the students' opinions, expectations, and experiences about online education.

\section{Establishment Validity and Reliability}

To ensure the validity and reliability of the results, we implemented peer information and member control (Yildirim \& Simsek, 2011). We held meeting with the qualitative research methods expert in the field of sociology to present our data and our approach to analysis. The expert asked questions about the processes. Review themes and analysis of themes and provided feedback on their appropriateness. The final version of determined themes and the study report were sent to 3 randomly selected participants. These participants (for member control) reported that the results were completely in line with their views.

In addition, in order to increase the reliability/validity and transferability of our results, we detailed our participants, how we selected them and both sample and data analysis processes.

\section{FINDINGS}

\section{Subjects}

The majority of the students are women $(n=30)$. Their age average was found to be $22.12 \pm 3.64$ and their average GPA was found to be $(3.30 \pm 0.35)$ according to the 4 point evaluation system. These students study in midwifery $(n=17)$, first aid and emergency $(n=12)$, nursing $(n=4)$, anesthesia technician $(n=3)$, occupational health and safety $(\mathrm{n}=2)$, medical imaging techniques $(\mathrm{n}=2)$ departments. The sociodemographic characteristics of the students can be seen in Table 2 . 


\section{Themes}

An agreement was made upon the five main themes and eight subthemes by the researchers. Those main themes are ambivalent feelings, feelings of advantages and disadvantages, the differences between online education than face to face education, the problems experienced, and recommendations.

\section{Theme One: Ambivalent Feelings}

It is understood that the students have different feelings and opinions than from the time when they first learned that they were going online. While some students were happy about it, the others were worried. Although their reasons for being happily varied, they said:

"Actually, I was happy since we were in the pandemic, I am glad that we are able to continue our classed." (P3).

"I liked it at first because it was hard for me to travel to the school. It takes 2 hours 45 minutes." (P37).

"It was good for me, actually because I am the kind of person who likes to hang out at home. And also, there is the fear of getting Corona of course." (P17).

Besides the students who were happy, it turned out that there were also some students who have feelings like anxiety, fear, surprise.

"I was sad since I would stay away from school, especially the internship." (P35).

"My first feelings were that online education affected me badly indeed because the lessons in the classroom were more exciting to me. The feeling that online education would cause my education to be incomplete affected me badly." (P20).

"I was scared, actually. I was scared of how would it be or problems caused by the internet if can we really do it." (P21).

"I was very surprised. I was sad because we had our lessons and internships. I thought it would be better for me and my job to have a face to face experience of them." (P18)

\section{Second Theme: The Feeling of Disadvantages}

\section{Subtheme One: Feelings of Advantages}

The advantages and disadvantages of online education for the students were aimed to be found out. It was revealed that they found their home environment comfortable for various reasons. However, it is also understood that being away from their school environment caused them to be also to drift apart from the university discipline. Although the students found their home comfortable at the beginning, the fact that their whole semester was going to be online changed their minds later.

"It is better to be at home, you are comfortable, you can enter your classes whenever you like. But you cannot discipline yourself or move forwards. You just do it because you have to, but this time, the things you learned are not permanent." (P36)

"The best thing for me is that it is a comfortable environment and there is no one so that you can listen however you like. The system is on record and our professor records the lesson so you can go back and watch it again. It is quite good." (P24)

"The best benefit of it is that it provides flexibility to the students instead of waking up and going to the school every morning. Joining education from home has also benefited in terms of costs." (P1)

"It both an advantage for us that our study, joining the classes, and doing our homework is at our own discretion and a disadvantage for some people who cannot perform their liabilities. I am happy for myself because I had never produced something before. Now, we have responsibilities of our own." (P9)

"We cannot miss a class, for example. If you are here at home today, you can have your lesson. Even if you are overslept you have the chance to have online education after you wake up." (P26) 


\section{Subtheme Two: Feeling of Disadvantages}

It turned out that the students had some disadvantages during online education because they had lessons early in the morning and internet connection problems.

"First of all, we are cut out of the school environment. I don't think that we have the same efficiency as our classes. Most of our classes were early in the morning and we missed some of them. Although we set our alarms we couldn't prepare ourselves since we would not go to school". (P30)

"However much I tried to focus on my lessons there was always slackness caused by the home environment. I was able to go and get me some water from the kitchen during the class." (P25)

"One of the disadvantages is that since the attendance was not obligatory, the classes had few students. For example, there were 15-20 students in a class. There were also some students who wished to enter the class but couldn't because of the internet or connection problems." (P13)

\section{Third Theme: The Difference between Online Education than Face to Face Education}

When students evaluate the difference between online education and face-to-face education, they told that they found especially the applied courses different and had difficulties in those courses.

\section{Subtheme One: The Differences between Theoretical Classes than Online Education}

It is revealed that the theoretical classes of the students were generally maintained in a quite similar way as to face to face education.

"There isn't much difference in theoretical classes because you basically just get general information." (P2)

"It can be said that they are the same. It is the same presentation, and we learn the same subject so there is no difference." (P15)

Although the students generally said that there was no difference in theoretical courses, it turned out that they couldn't be actively involved in their courses because of the reasons such as not being at an actual class, not wanting to interrupt the lesson, and the probability to have a problem in the system.

"For example, when we are in the class anyone could indicate their ideas by raising their hands, but when we had the lesson over a system not everyone was able to talk or indicate their ideas. Face to face communication is better. I thought it is better to see and hear everyone." (P29)

"Even catching the professor's eye can help you focus on something sometimes. You can be more active when you are in an actual class, you can listen more efficiently. Of course, you still learn something but it is more like watching a video when we are online." (P8)

"You cannot communicate your thought through messages in a theoretical class or sometimes when you are writing that message the professor already continues with the next page and you got cut off. And because of staying behind, you cannot get the complete answer you wished for. But if it were in a classroom environment, you would ask your question and explain what is the thing that you couldn't understand and make contact. I think eye contact is important." (P10)

"Actually, I don't think there is much difference in theoretical classes. There is just a tension caused by the fear that losing the internet connection. And also, the door is closed and the lesson continues whatever happens. However, at home, sometimes someone might walk into your room. Or anyone can come at any time to your house or anything can happen. I could push some wrong buttons or my voice might be recorded unintentionally." (P40)

\section{Subtheme Two: The Differences in Applied Courses than Online Education}

It was found that none of the students were satisfied with the fact that the applied courses which have crucial importance in the learning of the requirements of their jobs in health sciences were given online. The 
students who have their applied courses in laboratories or clinical environments are were away from these environments during online education. For this reason, it is understood that the student could not benefit from the applied courses enough.

"We were doing the practices in person when we were at school, but we can't now. For example, once we had given someone a birth at a class. We cannot do any of these things online. We cannot practice. We don't have any materials. We had at least our laboratory at school. We were able to do something there but none of this possible in online education." (P22)

"In the end, seeing something is quite different than actually doing it because you don't forget what you did. For example, if you tell a person how to drive a car for 5 years and tell him to sit and drive, he would definitely hesitate to do it. But if you show him how to do 5-6 times and then tell him to drive in traffic, he would be much comfortable. I think it is the same." (P19)

"I think it is a lot different. Since we all do the same thing at the school when we are in an applied course, I am able to see how my friends do it or how my professor does it. I can clearly see how my professor holds the patient and intervenes. We did not have a chance to practice in online education." (P18)

\section{Fourth theme: Problems Experienced}

The problems experienced in online education were analyzed under the headings of the problems caused by the students, problems caused by the system, and the problems caused by the educators.

\section{Subtheme One: Problems Caused by the Students}

The student-based problems faced during the online education are not being disciplined, the lack of opportunities, difficulty in concentration not attending classes because they think that their absence is not checked.

"I think, most of the students cannot attend the lesson at the same time. This is because of the flexibility they give us. The enthusiasm of other students is also harmed. There is a general lack of willingness. The students think like if no one is attending why should I?" (P1)

"I had problems on focusing. I am easily distracted by the tiniest noise when I am at school so I was more distracted at home sitting in front of the computer." (P37)

"The students did not do their homework. I had a chance to observe it since I was the class representative. They uploaded the homework for Professor A to Professor B. They asked to enter a make-up exam saying that they missed the final exam which was at 9 am. Everyone tried to direct the course as they wish by saying tell the professor to give less homework, to make the exam easy, or to prepare questions not one answer questions for the exam." (P6)

"None of us took responsibility and opened our cameras and microphones. We could have communicated with our professor in some ways. We preferred to stay back. It is because we expect everything from other people. But I think the biggest responsibility here was ours." (P22)

"We had delays in courses due to the irresponsibility of the students. The lesson is at 9 am. I usually enter the system at 8.55, one of them comes at 9.05 and the other at 9.10, and then they asked the professor to start over or repeat since they missed the beginning. They should be on time." (P23)

"We have some classmates who do not have the same opportunities as us. Some students' computers were broken, and they couldn't do their presentations. And everyone went to their hometowns. We don't know if the houses of each student are available, some of our friends did their presentations from their kitchen for example. It was hard for the ones who had these kinds of limitations. I saw that some of my friends had difficulties." (P40)

\section{Subtheme Two: Problems Caused by the System}

The problems caused by the system during online education were worries about the adaptation to the system at the beginning, and being kicked out of the system, not being able to log in, and internet connections in the following days. 
"At first, we couldn't figure out who was talking, where the noise was coming from or what we were doing. Later we got used to it." (P4)

"Sometimes we lost our connections. It was more at the beginning. Later, after we complied about it, it got better. Then we had individual internet problems." (P5)

"We did not have that many problems in the system, but it collapsed due to intensive use." (P7)

"We had this problem mostly in the sign language class. Our teacher wanted everyone to write down the gestures he makes. When 52 people send messages at the same time, the system of the students who use their phones used to freeze. So, they were not able to catch up. Most of them couldn't benefit from the class because they had to use their phones since they did not have a computer at home." (P33)

\section{Subtheme Three: Problems Caused by the Educators}

It was revealed that most of the students did not have any significant problems with the instructors during the online education process, and those who lived had problems due to lack of motivation and non-compliance with class hours.

"I say this with all my sincerity, I have never had any problems because of any of my professors. They all worked very hard, day and night. They sent us homework, and we sent them videos, they watched those videos and got back to us, they wrote to us our shortcomings." (P11)

"I think there was a lack of motivation. They were as if they had been talking by themselves rather than explaining something to the students. I think this is because they couldn't see us, they couldn't focus. I don't blame them, of course. They are right. They cannot focus on online education." (P38) "Some of our professors, for example, talk a lot, but they always say the same thing. They explain something that can be explained in 5 minutes for an hour, so we lose our interest. The lesson is 50 minutes, but it becomes a problem when we had to do it for 2 and a half hours instead." (P39)

"For example, some professors used to give lessons as they wish. We couldn't know exactly at what time we had a lesson. The professor used to say I am available at this our today." (P28)

\section{Fifth Theme: Recommendations}

The suggestions of the students to make more use of their lessons and participate more actively in online education were desired to be learned. Since they are students studying in health departments, their suggestions for theoretical and applied courses were asked separately.

\section{Subtheme One: Recommendations for Theoretical Courses}

Although the students did not have any suggestions for the improvement of online education regarding theoretical courses, subjects such as "monitoring absenteeism", "correcting system malfunctions", "assigning students to tasks or having their cameras turned on" emerged in order to ensure active participation of students in the course.

"I believe, the only solution for the theoretical courses is to make attendance obligatory." (P12)

"I think attendance should be taken in order for the attendance to be more. When you don't check the attendance, the students do not come to the class since they think it is not important. If the attendance is taken, the participants will be more. People wonder about something and ask it. In that case, not only one person but 50 people benefit from that question. Except for that, the problems in the system should be fixed." (P16)

"I wish it would be possible and everyone opened their cameras at the same time, but I don't know how they would follow everyone. Body language is very important. I would like the educators to see a person's reaction when they answered their questions. I would like them to hear all the talks at the same time, but I don't know how it would be possible." (P14) 
"Maybe it might look quite simple, but the only thing I can come up with right now is that maybe it would be better if we had more tasks and would be more active rather than the professors' getting ready and giving the lecture." (P27)

"It might be better if the problems in the system are fixed." (P32)

\section{Subtheme Two: Recommendations for the Applied Courses}

It is understood that their suggestions for applied courses are to have the courses in the clinic or the university practice laboratory by taking the necessary precautions even if the COVID pandemic continues.

"I don't think that we can have enough efficiency from the applied courses. We don't sketch something; we try to learn what we should do on the patient. I don't think that it would be possible to learn that without practicing on the patient." (P27)

"At least we should go to the school for our applied courses, even though they don't completely open the schools. We really need to take applied lessons. We should see childbirth, risky birth, gynecology, children lessons in person." (P31)

"Our professional life will be hard if we don't know how to apply. Applied courses should be face to face, not online." (P32)

"We did our presentations about cases. Our professors asked questions as if we really were there, still, it was good. At that time we thought like it was a real patient, but nothing replaces real-life practices. Practicing with a real patient is never the same as practicing with an imaginary one." (P34)

"I don't know if it is possible, but if we won't go to the school, maybe there may be an agreement with a hospital from our region. I want to do my internship anyways." (P28)

\section{DISCUSSION}

Students experienced different feelings such as joy and anxiety in the first days of the distance education. Although it is enjoyable to be included in their lessons with home comfort in distance education, it is understood that they stay away from school discipline. They stated that the theoretical courses were not much different from the university environment, and that their applied courses were inefficient. Finally, it is understood that they are experiencing systemic problems and some of them due to the instructor.

With the COVID pandemic, schools have been closed all over the world and different solutions have been produced to ensure uninterrupted education (Gilani, 2020). University education in Turkey and all over the world in order to maintain internet-connected platforms are utilized (Chang \& Satako, 2020). Continuing education remotely within the scope of the pandemic is effective in reducing the disease rate and reducing the burden on the health system (Gianni \& Lewis, 2020). Similarly, the students who participated in this study stated that they were glad that they would stay away from the disease when they first heard that the education would continue online. However, it is understood that the prolongation of the online education period causes them to stay away from the university environment and their friends and to decrease their social interactions. Similarly, it is stated that continuing education remotely can lead to a decrease in social interaction of young people and social isolation (Chang \& Satako, 2020).

The students participating in the study evaluated the conditions that do not force them, such as benefiting from flexible hours in online education and not having to go to the campus, as an advantage. The underlying reason for this assessment can be attributed to the self-determination theory. Self-determination is an important concept in education. Self-determination is described as the determination of the behavior with an individual's own values rather than group or community pressure (Martela, 2020). According to this theory, people have 3 universal psychological needs (relatedness, competence, and autonomy) that have positive consequences if they are supported and negative consequences if they are prevented (Ryan \& Deci, 2000). Competence of them, is related to feeling competent and successful while autonomy is feeling that there is a chance to choose instead of being forced (Milyavskaya et al., 2009; Ryan \& Brown, 2003). However, the fact that students stated that their friends do not participate in online education and that participation 
in compulsory lessons should be ensured by attendance contradicts this theory. The underlying reason for these thoughts may be their motivational behavior. In the extrinsic regulation type of motivation, there is a submissive behavior and a tendency to avoid reward or punishment in the context of an extrinsic causality (Ryan \& Deci, 2020). In the intrinsic type of motivation, individuals escape from internal punishment (such as feeling guilty, fear, or worry) or act to get an internal reword that enhances the ego, such as boast (Ryan \& Deci, 2020). Generally, the underlying reason for the students indicating that they attended the classes might be the expectancy to see ego enhancing behavior such as reward and appreciation.

It was revealed that students had some problems such as having insufficient environmental conditions, computer and internet connection. Students studying at a university usually do not have socio-economical independence. For this reason, they live with their parents within the opportunities they provide. Studies indicate that the academic success of a student is related to the socio-economic situation of their families, especially at an early age (Reichelt et al., 2019; Shavit \& Muller, 2000). In parallel with the literature, even though the students' grade point averages are high $(3.30 \pm 0.35)$, the fact that the students participating in the study do not have their own rooms shows the underlying reason for participating in the lesson on mobile phones instead of computers is due to their poor socio-economic status. On the other hand, when the students cannot find a computer, they can attend the lessons on their mobile phones, showing that they are willing to learn. Similarly, Kamali et al. indicated that the network environment is important for the education of the students; however, electronic devices have a limited effect (Kamali \& Kianmehr, 2015). Still, it shouldn't be forgotten that the quality of education highly dependent on digital access opportunities and quality (Gilani, 2020). Of course, the underlying reason for this result may be having a good communication network. It is reported that the systems used for distance education are generally evaluated by users as "very heavy". As a result, Software upgrades by the system providing companies is of vital importance (Chen et al., 2020). Distance learning researches began at the end of the 1700s around the world has been being used in Turkey since the 1980s (Bozkurt, 2017). Although distance education has been used in Turkey for a very long time, a rapid transition to online education in schools of all levels due to the pandemic might have caused some problems. However, as stated in the study conducted by UNESCO department head of education policies Chang in 84 countries, "evaluation of the progress of students to identify learning gaps and remedial learning opportunities when schools are opened" should be offered (UNESCO, 2020c). The students said that they had problems such as disconnection, freezing of the images especially in the first days of online education. It is stated in the studies evaluating online education satisfaction in students that stuck or disconnections reduce satisfaction (Asarbakhsh \& Sardars, 2013; Rajab et al., 2020b).

It was revealed that the students cannot benefit from especially applied courses in online education compared to face-to-face education, and the lack of motivation of the professors negatively reflected on the students. Studies indicate that the students' perception of use about the education they have, active participation in the lesson, the response time of the instructor, and consultation are important (Erdemir et al., 2016). Likewise, students report that they perform a more satisfactory training when they perform their clinical practice with a supervisor assigned to them (Pitkanen et al., 2018). On the other hand, generation can be influential in students' educational preferences. For example, although generation $\mathrm{Z}$ prefers face-to-face communication with the lecturer physically in education (Cilliers, 2017; Ramadlani \& Wibisono, 2017). The fact that the students participating in this study are from a similar generation may have affected their preferences regarding education. However, it shouldn't be forgotten that online education affects not only students but also the instructors. Perceval and Tejedor state five levels of communication for building a connection between students and instructors in online education. Oral-gestural and audiovisual communication are two of them (PercevalVerde $\&$ Tejedor-Calvo, 2008). The fact that online education provides limited communication opportunities in terms of audiovisual and oral-gestural can cause problems for both the student and the instructor.

On the other hand, positive opinions were reported on online education during the Covid epidemic in a study conducted with medical school students and academicians. Academicians have noted that good education can always be provided in person or online. (Rajab et al., 2020a). Seeing only the face of the instructors negatively affects the motivation of the students, and it is thought that the fact that the instructors teach by looking at the screen decreases their motivation. 


\section{LIMITATIONS}

There are some limitations to this study. The fact that this study is conducted by the instructors might have caused the students to hesitate in communicating their opinions and experiences explicitly. Also, it is hard to generalize the result of the study to all students since the study is conducted with students from 2 different universities.

\section{CONCLUSIONS}

Students studying in health departments are candidates for future healthcare professionals. So, in this process, possible problems related to education may cause difficulties in their professional life. In addition, there was no qualitative study that detailed student experiences in online education during the pandemic. This study revealed the opinions and feelings of the students studying in health departments about online education during the pandemic and their problems and recommendations about applied courses. In addition, it has been understood that the students have problems arising from the system, and to a lesser extent, from faculty members.

Acknowledgments: We thank and appreciate all the students who participate in the study.

\section{BIODATA and CONTACT ADDRESSES of AUTHORS}

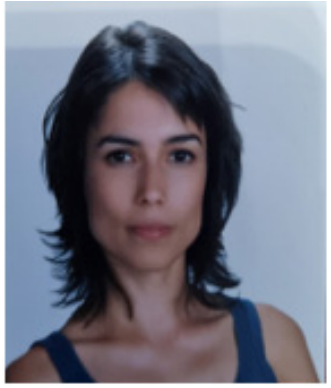

Dilek BAYKAL is an Assistant Professor of Department of Nursing of Health Sciences, Istanbul Atlas University. Dr. Baykal gained his Ph.D. in Istanbul University, department of internal medicine nursing, 2018. Her academic interest areas are neurologic disease, caregivers, oncology, open and distance learning, education futures, e-learning, cyber behaviors and use of internet in education. She has over than 3 journal articles published in international indexes, 2 international book chapters and other national and international articles, papers submitted to international meetings.

Dilek BAYKAL

Department of Nursing, Faculty of Health Sciences

Address: Istanbul Atlas University, 34408, Istanbul, Turkey

Phone: +904443439

E-mail: dilek.baykal@atlas.edu.tr

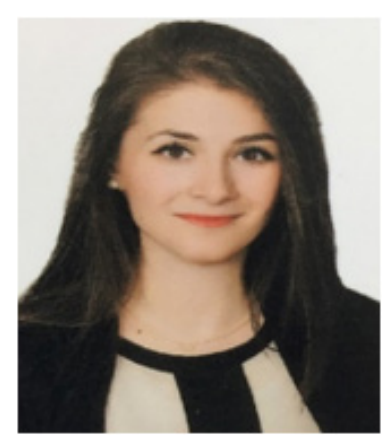

Sema KOC TUTUNCU is a Research Assistant of Vocational School, Medical Services and Techniques Department, First aid Program, Maltepe University. Tutuncu finished his master program in Halic University, department of nursing, 2013. Her academic interest areas are cardiology, ethics, quality of health, learning and education. She has over than 5 journal articles published international articles, 1 national book chapters.

\section{Sema KOC TUTUNCU}

Medical Services and Techniques Department, Vocational School

Address: Maltepe University, 34843, Istanbul, Turkey

Phone: +90 4440620

E-mail: sematutuncu@maltepe.edu.tr 


\section{REFERENCES}

Akbulut, M., Sahin, U., \& Esen, A. C. (2020). More than a Virus: How COVID 19 Infected Education in Turkey? Journal of Social Science Education, 19, 30-42. https://doi.org/10.4119/jsse-3490

Aker, S., \& Midik, O. (2020). The Views of Medical Faculty Students in Turkey Concerning the COVID-19 Pandemic. Journal of Community Health, 1. https://doi.org/10.1007/s10900-020-00841-9

Asarbakhsh, M., Sandars, J. (2013). E-learning: The essential usability perspective. Clin. Teach., 10, 47-50. https://doi.org/ 10.1111/j.1743-498X.2012.00627.x

Bozkurt, A. (2017). Turkiye'de uzaktan egitimin dunu, bugunu ve yarini. Acikogretim Uygulamalari ve Arastirmalari Dergisi, 3 (2),85-124. Retrieved from https://dergipark.org.tr/en/download/articlefile/403827

Brashers, V., Erickson, J. M., Blackhall, L., Owen, J. A., Thomas, S. M., \& Conaway, M. R. (2016). Measuring the impact of clinically relevant interprofessional education on undergraduate medical and nursing student competencies: a longitudinal mixed methods approach. Journal of Interprofessional Care, 30(4), 448-457. https://doi.org/10.3109/13561820.2016.1162139

Chang, G.C.\& Satako, Y. (2020). How are countries addressing the Covid-19 challenges in education? A snapshot of policy measures. Retrieved from https://gemreportunesco.wordpress.com/2020/03/24/ how-are-countries-addressing-the-covid-19-challenges-in-education-a-snapshot-of-policymeasures/communication in education

Chen, T., Peng, L., Jing, B., Wu, C., Yang, J., \& Cong, G. (2020). The Impact of the COVID-19 Pandemic on User Experience with Online Education Platforms in China. Sustainability, 12(18), 7329. https://doi.org/10.3390/su12187329

Cilliers, E.J. (2017). The challenge of teaching generation Z. People Int J Soc Sci, 3, 188-98. 10.20319/ pijss.2017.31.188198

Council of Higher Education. Press briefing. Retrieved Sept 16, 2020 https:/www.yok.gov.tr/Sayfalar/ Haberler/2020/universitelerde-uygulanacak-uzaktan-egitime-iliskin-aciklama.aspx

COVID-19 Information page. Retrieved Sep 16, 2020 https://covid19.saglik.gov.tr/?_Dil=2

Cucinotta, D., \& Vanelli, M. (2020). WHO declares COVID-19 a pandemic. Acta Bio-Medica: Atenei Parmensis, 91(1), 157-160. https://doi.org/10.23750/abm.v91i1.9397

Culyer, L. M., Jatulis, L. L., Cannistraci, P., \& Brownell, C. A. (2018). Evidenced-Based Teaching Strategies that Facilitate Transfer of Knowledge Between Theory and Practice: What are Nursing Faculty Using?. Teaching and Learning in Nursing, 13(3), 174-179. https://doi.org/10.1016/j. teln.2018.03.003

Erdemir, A., Cavdar, D., Bagci, V., \& Corbaci, E. C. (2016). Factors Predicting e-Learners' Satisfaction on Online Education. In Proceedings of The Multidisciplinary Academic Conference (pp. 53-60). Retrieved from

https://books.google.com.tr/s?hl=tr\&lr=\&id=McrRDAAAQBAJ\&oi=fnd \&pg=PA53\&dq=Erdemir,+A., +\%C3\%87avdar,+D.,+Ba\%C4\%9Fc\%C4\%B1,+V.,+\%26+\%C3\%87orbac\%C4\%B1,+E.+C.+ (2016).+Factors+Predicting+e-Learners\%27+Satisfaction+on+Online+Education.+In+Proceed ings+of+The+Multidisciplinary+Academic+Conference+(pp.+53-60).\&ots=x9snHbWKjI\&sig$=I X X k 6 X Q u f E 5 j 1$ VKCfZI451gCcJ8\&redir_esc=y\#v=onepage\&q\&f=false

Ertug, C. (2020). Coronavirus (Covid-19) pandemisi ve pedagojik yansimalari: Turkiye'de acik ve uzaktan egitim uygulamalari. Acikogretim Uygulamalari ve Arastirmalari Dergisi, 6(2), 11-53. Retrieved from https://dergipark.org.tr/tr/pub/auad/issue/55662/761354

ETF, (2020). Coping with COVID-19: Mapping education and training responses to the health crisis in ETF partner countries. Torino: ETF Publishing. Retrieved from http://hdl.voced.edu. $\mathrm{au} / 10707 / 540321$. 
Giannini, S. \& Lewis, G.S. (2020). Three ways to plan for equity during the coronavirus school closures. Retrieved from https://gemreportunesco.wordpress.com/2020/03/25/three-ways-to-plan-forequity-during-the-coronavirus-school-closures/.

Gilani, I. (2020). Coronavirus pandemic reshaping global education system? Retrieved Jan 092020 , https://www.aa.com.tr/en/education/coronavirus-pandemic-reshaping-global-educationsystem/1771350

Kamali, A. \& Kianmehr, L. (2015). The Paradox of Online Education: Images, Perceptions, and Interests. Us-China Educ. Rev. A, 9, 591-601. https://doi.org/10.17265/2161-623X/2015.09A.002

Keskin Kiziltepe, S., \& Kurtgoz, A. (2020). Determination of Nursing Student's Attitudes and Views Towards Distance Learning During the Covid-19 Pandemic Process. Journal of International Social Research, 13(74). Retrieved from http://eds.a.ebscohost.com/t?site=e $\mathrm{d}$ \&scope $=$ site $\& \mathrm{rnnl}=13079581 \& \mathrm{AN}=147835618 \& \mathrm{~h}=\mathrm{iFUVagxREuKeWBu} 8 X 1 \mathrm{gjMPGl}$ VkRO\%2brsavlgCL3myTY7Z2CQyX0HkJY5qQcS8RbcUZ\%2fXS9f0nQlXH1Y4fgEw $\mathrm{DVg} \% 3 \mathrm{~d} \% 3 \mathrm{~d} \& \mathrm{crl}=$ f\&resultLocal=ErrCrlNoResults\&resultNs=Ehost\&crlhashurl=login. scope\%3dsite\%26authtype\%3dcrawler\%26jrnl\%3d13079581\%26AN\%3d147835618

Krippendorff, K. (2013). Content analysis: An introduction to its methodology. Thousand Oaks, CA: Sage. Retrieved from https://books.google.com.tr/n\&lr=\&id=nE1aDwAAQBAJ\&oi=fnd\&pg $=$ PP1\&dq=Krippendorff, + K. $+(2013) .+$ Content + analysis $:+A n+$ introduction + to + its + methodol ogy.+Thousand+Oaks,+CA:+Sage.++\&ots=yZ8mWwkR9u\&sig=H17DKvoJgQr1TIsk6HlP_ yRhbNE\&redir_esc $=y \# v=$ onepage\&q\&f=false

Martela, F. (2020). Self-Determination Theory. The Wiley Encyclopedia of Personality and Individual Differences: Models and Theories, 369-373. https://doi.org/10.1002/9781118970843.ch61

Milyavskaya, M., Gingras, I., Mageau, G. A., Koestner, R., Gagnon, H., Fang, J., \& Boiche, J. (2009). Balance across contexts: Importance of balanced need satisfaction across various life domains. Personality and Social Psychology Bulletin, 35(8), 1031-1045. https://doi.org/10.1177/0146167209337036

Ozdin, S., \& Bayrak Ozdin, S. (2020). Levels and predictors of anxiety, depression and health anxiety during COVID-19 pandemic in Turkish society: The importance of gender. International Journal of Social Psychiatry. 66(5),1-8. https://doi.org/10.1177/0020764020927051

Ozer, M. (2020a). The contribution of the strengthened capacity of vocational education and training system in Turkey to the fight against Covid-19. Yuksekogretim Dergisi, 10(2), 134-140. https:// doi.org/10.2399/yod.20.726951

Ozer, M. (2020b). Educational Policy Actions by the Ministry of National Education in the times of COVID-19. Kastamonu Education Journal, 28(3), 1124-1129. https://doi.org/10.24106/ kefdergi. 722280

Perceval-Verde, J. M., \& Tejedor-Calvo, S. (2008). Oral-gestural, writing, audio, audiovisual and... digital? The five degrees of communication in education. Comunicar: Revista Científica de Comunicación y Educación, 15(30), 155-163. https://doi.org/10.3916/c30-2008-02-009

Pinar, M. A., \& Donel Akgul, G. (2020). The opinions of secondary school students about giving science courses with distance education during the covid-19 pandemic. Journal of Current Researches on Social Sciences, 10(2), 461-486. https:// doi.org/10.26579/jocress.377

Pitkanen, S., Kaariainen, M., Oikarainen, A., Tuomikoski, A. M., Elo, S., Ruotsalainen, H., ... \& Mikkonen, K. (2018). Healthcare students' evaluation of the clinical learning environment and supervision-a cross-sectional study. Nurse Education Today, 62, 143-149. https://doi.org/ 10.1016/j.nedt.2018.01.005

Polit, D. F., \& Beck, C. T. (2010). Generalization in quantitative and qualitative research: Myths and strategies. International Journal of Nursing Studies, 47(11), 1451-1458. https://doi.org/ 10.1016/j.ijnurstu.2010.06.004

Rajab, M. H., Gazal, A. M., \& Alkattan, K. (2020a). Challenges to online medical education during the COVID-19 pandemic. Cureus, 12(7). https://doi.org/10.7759/cureus.8966 
Rajab, M. H., Gazal, A. M., Alkawi, M., Kuhail, K., Jabri, F., \& Alshehri, F. A. (2020b). Eligibility of medical students to serve as principal investigator: an evidence-based approach. Cureus, 12(2). https://doi.org/10.7759/cureus.7025

Ramadlani, A.K., \& Wibisono, M. (2017). Visual literacy and character education for alpha generation. In: proceedings of the International seminar on language, education and culture. Malang: Faculty of Letters, Universitas Negeri Malang, 1-7. Retrieved from http://sastra.um.ac.id/wp-content/ uploads/2017/11/01-07-Abdul-Khaliq-Ramadlani-Marko-Wibisono_LAYOUTED.pdf

Reichelt, M., Collischon, M., \& Eberl, A. (2019). School tracking and its role in social reproduction: Reinforcing educational inheritance and the direct effects of social origin. The British Journal of Sociology, 70(4), 1-26. https://doi.org/10.1111/1468-4446.12655

Reimers, F. M. (2020). What the Covid-19 Pandemic will change in education depends on the thoughtfulness of education responses today. Worlds of Education. Retrieved Jan 10, 2020 https://www. worldsofeducation.org/en/woe_homepage/woe_detail/16727/\%E2\%80\%9Cwhat-the-covid19-pandemic-will-change-in-education-depends-on-the-thoughtfulnessofeducation-responsestoday $\% \mathrm{E} 2 \% 80 \% 9 \mathrm{D}$-by-fernando-mreimers

Ryan, R. M., \& Brown, K. W. (2003). Why we don't need self-esteem: On fundamental needs, contingent love, and mindfulness. Psychological Inquiry, 14(1), 71-76. Retrieved from https://www.jstor.org/ stable/1449046?seq=2\#metadata_info_tab_contents

Ryan, R. M., \& Deci, E. L. (2000). When rewards compete with nature: The undermining of intrinsic motivation and self-regulation. In Intrinsic and Extrinsic Motivation (pp. 13-54). Academic Press. https://doi.org/10.1016/B978-012619070-0/50024-6

Ryan, R. M., \& Deci, E. L. (2020). Intrinsic and extrinsic motivation from a self-determination theory perspective: Definitions, theory, practices, and future directions. Contemporary Educational Psychology, 101860. https://doi.org/10.1016/j.cedpsych.2020.101860

Shavit, Y., \& Muller, W. (2000). Vocational secondary education: Where diversion and where safety net? European Societies, 2(1),29-50. https://doi.org/10.1080/146166900360710

UNESCO, (2020a). How are countries addressing the Covid-19 challenges in education? A snapshot of policy measures. Global Education Monitoring Reports. Paris: United Nations Educational, Scientific and Cultural Organization. Retrieved from https://gemreportunesco.wordpress. com/2020/03/24/how-are-countries-addressing-the-covid-19-challenges-in-education-asnapshot-of-policy-measures/

UNESCO, (2020b, March 27). Teacher Task Force calls to support 63 million teachers touched by the COVID-19 crisis. UNESCO. Retrieved Sep 08, 2020 https://en.unesco.org/news/teacher-taskforce-calls-support-63-million-teachers-touched-covid-19-crisis

UNESCO, (2020c). Exams and assessments in COVID-19 crisis: fairness at the centre. Retrieved from https://en.unesco.org/news/exams-and-assessments-covid-19-crisis-fairness-centre.

Yildirim, A., \& Simsek, H. (2011). Sosyal bilimlerde nitel arastirma yontemleri [Qualitative research methods in social sciences]. Ankara: Seckin Yayinevi. Retrieved from https://dergipark.org.tr/tr/ download/article-file/63326 